\title{
Bcl-2 Inhibitor BCL201
}

National Cancer Institute

\section{Source}

National Cancer Institute. BCl-2 Inhibitor BCL201. NCI Thesaurus. Code C125603.

A selective inhibitor of the anti-apoptotic protein B-cell lymphoma 2 ( $\mathrm{Bcl}-2)$, with potential pro-apoptotic and antineoplastic activities. Upon administration, BCl-2 inhibitor BCL201 binds to and inhibits the activity of $\mathrm{Bcl}-2$. This restores apoptotic processes in tumor cells. $\mathrm{Bcl}-2$ protein is overexpressed in many cancers and plays an important role in the negative regulation of apoptosis; its expression is associated with increased drug resistance and tumor cell survival. 